\title{
Reduced sensitivity of the renal vasculature to angiotensin II in young rats: the role of the angiotensin type 2 receptor
}

\author{
Russell D. Brown', Lucinda M. Hilliard', Katrina M. Mirabito', Laura C. Firth', Karen M. Moritz², Roger G. Evans' and \\ Kate M. Denton'
}

BACKGROUND: The angiotensin type-2 receptor (AT $\mathrm{R}$ ) opposes the vasoconstrictor actions of angiotensin II (Angll) mediated through the angiotensin type-1 receptor (AT,R). Renal $A T_{2} R$ levels are high during fetal life, but decrease significantly during postnatal maturation. To provide insight into the functional role of the AT $R$ in the kidney during postnatal development, we investigated the effects of $\mathrm{AT}_{2} R$ antagonism on cardiovascular responses to Angll in young and adult male rats.

METHODS: In anesthetized 3- and 6-wk-old male SpragueDawley rats, mean arterial pressure (MAP) and renal blood flow (RBF) were measured in response to Angll in the presence of vehicle treatment or AT ${ }_{2}$ b blockade with PD123319.

RESULTS: The pressor effect of Angll and associated reduction in RBF were significantly less in 3-wk- than 6-wk-old rats. $\mathrm{AT}_{2} \mathrm{R}$ blockade potentiated the reduction in RBF in response to Angll in 3-wk-old rats only.

CONCLUSION: In young rats, the $\mathrm{AT}_{2} \mathrm{R}$ modulates the response to Angll, blunting renal vasoconstriction. This effect is attenuated with age in association with a developmental reduction in renal $A T_{2} R$ expression. These findings may have implications for the development of novel therapies that target the reninangiotensin system for the improvement of renal function in term and, in particular, preterm infants.

l: n healthy term infants, sufficient organ blood flow is maintained by relatively low systemic arterial pressure. However, preterm infants demonstrate a significant risk of hypotension and so inadequate perfusion of vascular beds, including the renal circulation (1). This is generally considered a result of either a delay in, or failure of, the hemodynamic changes that take place during the transition from fetal to newborn life; that is, the effective transition from the in utero to the ex utero circulation (2,3). Improved understanding of the neonatal cardiovascular system under normal physiological conditions is thus essential for the identification of more effective therapeutic strategies for infants with circulatory compromise, and to prevent severe complications such as renal failure.
The kidney plays a major role in the long-term regulation of arterial pressure and extracellular fluid volume homeostasis. It is well established that renal blood flow (RBF) is initially low after birth due to high renal vascular resistance in healthy term infants. However, as the kidney undergoes postnatal structural and functional changes, RBF progressively increases to adult levels $(4,5)$. This developmental increase in RBF as the kidney matures is attributable to a striking reduction in renal vascular resistance that takes place during the postnatal period (4). This is, at least in part, due to developmental changes in the balance of vasoconstrictor and vasodilator forces in the kidney, including the renin-angiotensin system (RAS), which is integral to the growth, development, and function of the kidney $(1,4)$.

The main effector peptide of the RAS, angiotensin II (AngII), acts via two main receptor types: angiotensin type- 1 receptors and angiotensin type- 2 receptors $\left(A T_{1} R\right.$ and $\left.A_{2} R\right)$. The $A T_{1} R$ and $\mathrm{AT}_{2} \mathrm{R}$ subtypes exert opposing effects on the regulation of arterial pressure and cell growth and survival (6). The $\mathrm{AT}_{1} \mathrm{R}$ is responsible for mediating vasoconstriction, sodium retention, and cellular growth and proliferation. In contrast, the $\mathrm{AT}_{2} \mathrm{R}$ acts to counterbalance $\mathrm{AT}_{1} \mathrm{R}$-mediated effects by promoting vasodilatation, sodium excretion, apoptosis, and antigrowth effects (7). The RAS is highly activated during the perinatal period (immediately prior to and following birth). This is evidenced by increased plasma renin activity and plasma AngII levels prior to birth and further increases after birth (8-10). However, as postnatal maturation proceeds and the kidneys of the newborn undergo major structural and functional changes in order to assume responsibility for the regulation of extracellular fluid volume homeostasis and arterial pressure, plasma renin activity and circulating AngII levels progressively decline (8-10). Furthermore, $\mathrm{AT}_{1} \mathrm{R}$ and $\mathrm{AT}_{2} \mathrm{R}$ expression within the kidney is developmentally regulated. Both receptors are highly expressed in the fetal and neonatal kidney and their expression progressively decreases after birth (11-15). However, $\mathrm{AT}_{2} \mathrm{R}$ levels decrease to a greater extent such that the $\mathrm{AT}_{1} \mathrm{R}$ predominates in the adult kidney (11).

To date, the functional role of the $\mathrm{AT}_{2} \mathrm{R}$ during postnatal kidney development has not been completely elucidated. Given 
its documented vasodilatory effects, it is highly plausible that this receptor may play a critical role in the immature kidney, counteracting AT $\mathrm{R}_{1}$-mediated vasoconstrictor effects of AngII and subsequently facilitating the postnatal rise in RBF. Insight into the physiological role of the $\mathrm{AT}_{2} \mathrm{R}$ in early life could have important implications for the identification of novel therapies that target the RAS for the improvement of renal function, particularly in preterm infants in whom postnatal kidney maturation is delayed. Therefore, in this study, we aimed to investigate the renal vascular responses to AngII of young (3-wk old) and adult (6-wk old) male rats, and the contributions of the $\mathrm{AT}_{2} \mathrm{R}$ at each of these ages. It was our hypothesis that the relative expression of the $\mathrm{AT}_{1} \mathrm{R}$ vs. $\mathrm{AT}_{2} \mathrm{R}$ influences the sensitivity to AngII in the immature rat kidney, such that 3-wk-old rats are less sensitive to the vasoconstrictor effects of AngII than 6-wkold rats.

\section{RESULTS}

\section{Baseline Variables}

Body weight (BW) and left kidney wet weight $(\mathrm{KW})$ were significantly less in 3-wk-old rats (BW: $44 \pm 1 \mathrm{~g}$; KW: $0.35 \pm 0.03 \mathrm{~g}$ ) than 6-wk-old rats (BW: $129 \pm 6 \mathrm{~g} ; \mathrm{KW}: 0.69 \pm 0.05 \mathrm{~g})(P<$ $0.001)$. Similarly, basal recordings of mean arterial pressure (MAP) and RBF were significantly less in the 3-wk-old than 6-wk-old rats $(P<0.001)$. In the 3 -wk-old rats, MAP and RBF were $72 \pm 4 \mathrm{mmHg}$ and $2.8 \pm 0.3 \mathrm{ml} / \mathrm{min} / \mathrm{g} \mathrm{KW}$ at baseline, respectively. In comparison, in the 6-wk-old rats, basal $\mathrm{MAP}$ and RBF were $89 \pm 4 \mathrm{mmHg}$ and $4.1 \pm 0.4 \mathrm{ml} / \mathrm{min} / \mathrm{g} \mathrm{KW}$, respectively.

\section{Response to Angll}

There were significant effects of both dose and age on the responses of MAP and RBF to AngII (results of repeated-measures ANOVA: $P_{\mathrm{Age}}<0.01, P_{\text {Dose }}=0.02$, and $P_{\text {Interaction }}=0.4$ for MAP; $P_{\text {Age }}<0.001, P_{\text {Dose }}<0.001$, and $P_{\text {Interaction }}=0.02$ for RBF; Figure 1). For example, in the 3-wk-old rats, MAP increased by $1.4 \pm 0.5 \%$ and $6.1 \pm 2.4 \%$ from baseline in response to 10 and $100 \mathrm{ng} / \mathrm{kg} / \mathrm{min}$ AngII, respectively. In comparison, in the 6-wk-old rats, MAP increased by $9.5 \pm 6.2 \%$ and $18.0 \pm 5.2 \%$ in response to 10 and $100 \mathrm{ng} / \mathrm{kg} / \mathrm{min}$ AngII, respectively. There was no significant difference in the pressor response to $10 \mathrm{vs.}$ $100 \mathrm{ng} / \mathrm{kg} / \mathrm{min}$ AngII on MAP in the 3-wk-old rats. Whereas, there was a trend for the increase in MAP to be significantly greater in response to $100 \mathrm{ng} / \mathrm{kg} / \mathrm{min}$ than $10 \mathrm{ng} / \mathrm{kg} / \mathrm{min}$ AngII in the 6-wk-old rats $(P=0.065)$. Moreover, the pressor response to $100 \mathrm{ng} / \mathrm{kg} / \mathrm{min}$ AngII was significantly greater in the 6-wk-old vs. 3 -wk-old rats $(P<0.05)$.

In terms of RBF, we observed a $2.1 \pm 1.0 \%$ and $10.0 \pm 2.8 \%$ reduction in RBF from baseline in response to 10 and $100 \mathrm{ng} /$ $\mathrm{kg} / \mathrm{min}$ AngII, respectively, in the 3-wk-old rats. Whereas, in the 6-wk-old rats RBF decreased by $8.3 \pm 2.6 \%$ and $30.8 \pm 6.6 \%$, respectively, in response to 10 and $100 \mathrm{ng} / \mathrm{k} / \mathrm{min}$ AngII. There was no significant difference in the RBF response to 10 vs. $100 \mathrm{ng} / \mathrm{kg} / \mathrm{min}$ AngII in the 3-wk-old rats. However, the reduction in RBF was significantly greater in response to $100 \mathrm{ng} / \mathrm{kg} /$ min than $10 \mathrm{ng} / \mathrm{kg} / \mathrm{min}$ AngII in the 6-wk-old rats $(P<0.001)$.

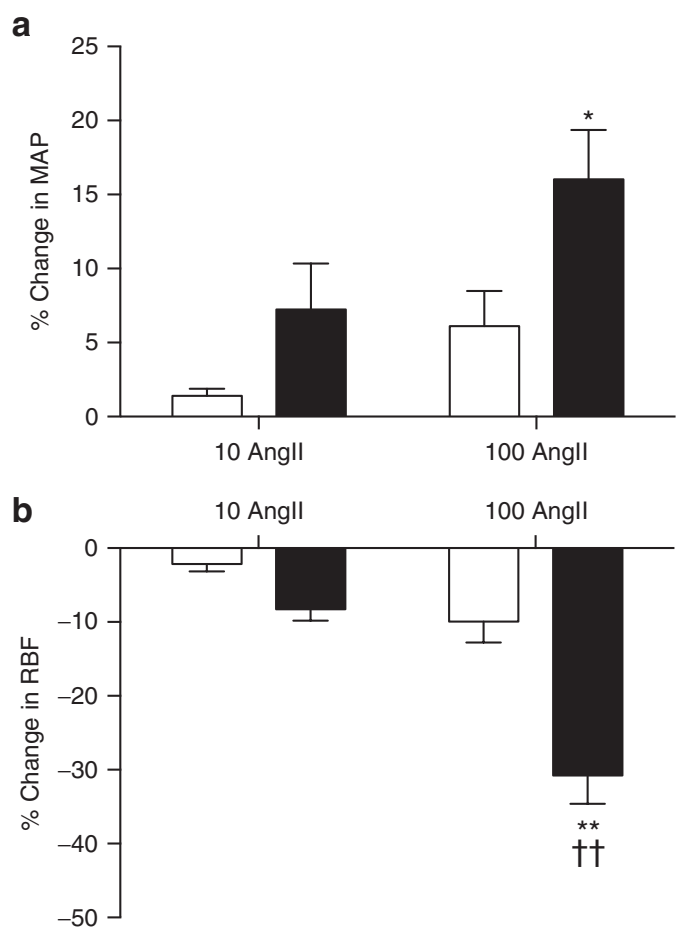

Figure 1. Pressor and renal vascular responses to angiotensin II. Percent change in (a) mean arterial pressure (MAP) and (b) renal blood flow (RBF) from baseline in response to intravenous infusion of angiotensin II (Angll; 10 and $100 \mathrm{ng} / \mathrm{kg} / \mathrm{min}$ ) in 3-wk-old (white bars) and 6-wk-old (black bars) male Sprague-Dawley rats. Data are presented as mean \pm SEM. $n=6$ per group. Data were analyzed using repeated-measures ANOVA using the factors age, dose, and the interaction between age and dose, followed by Bonferroni's post hoc tests. ${ }^{*} P<0.05$ and ${ }^{* *} P<0.001 \mathrm{vs}$. the response of 3 -wk-old rats to $100 \mathrm{ng} / \mathrm{kg} / \mathrm{min}$ Angll. ${ }^{+t} P<0.001 \mathrm{vs}$. the response of 6 -wkold rats to $10 \mathrm{ng} / \mathrm{kg} / \mathrm{min}$ Angll.

Moreover, the decrease in RBF in response to $100 \mathrm{ng} / \mathrm{kg} / \mathrm{min}$ AngII was significantly greater in the 6 -wk-old vs. 3 -wk-old rats $(P<0.001)$.

The influence of $\mathrm{AT}_{2} \mathrm{R}$ inhibition with PD123319 on the MAP and RBF response to AngII is shown in Figure 2. In the 3-wk- and 6-wk-old rats, there was no significant effect of PD123319 treatment on the MAP response to $100 \mathrm{ng} / \mathrm{kg} /$ min AngII (results of repeated-measures ANOVA: $P_{\text {Age }}=0.2$, $P_{\text {Treatment }}=0.4$, and $\left.P_{\text {Interaction }}=0.1\right)$. However, there were significant effects of PD123319 treatment on the RBF response to $100 \mathrm{ng} / \mathrm{kg} / \mathrm{min}$ AngII that were dependent on age (results of repeated-measures ANOVA: $P_{\mathrm{Age}}<0.01, P_{\text {Treatment }}<0.06$, and $\left.P_{\text {Interaction }}=0.005\right)$. Specifically, $\mathrm{AT}_{2} \mathrm{R}$ blockade potentiated the reduction in RBF in response to $100 \mathrm{ng} / \mathrm{kg} / \mathrm{min}$ AngII in the 3 -wk-old rats, resulting in a 1.3-fold decrease in $\mathrm{RBF}(P<0.01$ vs. RBF response to $100 \mathrm{ng} / \mathrm{kg} / \mathrm{min}$ AngII in the absence of PD123319). In comparison, we did not observe any significant effect of $\mathrm{AT}_{2} \mathrm{R}$ blockade with PD123319 on the RBF response to $100 \mathrm{ng} / \mathrm{kg} / \mathrm{min}$ AngII in the 6-wk-old rats.

\section{$A T_{1} R$ and $A T_{2} R$ mRNA Expression}

Renal $A_{1 a} R, A_{1 b} R$, and $A T_{2} R$ mRNA expression decreased significantly with age (Figure 3). Renal $\mathrm{AT}_{1 \mathrm{a}} \mathrm{R}, \mathrm{AT}_{1 \mathrm{~b}} \mathrm{R}$, and 
$\mathrm{AT}_{2} \mathrm{R}$ mRNA expression were significantly greater in the 3-wkold than the 6 -wk-old rats $\left(P_{\text {Age }}<0.001\right.$ each). Furthermore, these data indicate that with age, $\mathrm{AT}_{2} \mathrm{R}$ mRNA expression decreases to a greater extent than $\mathrm{AT}_{1} \mathrm{R}$ expression. Expression of $\mathrm{AT}_{1} \mathrm{R}$ mRNA was approximately fivefold less in the kidneys of 6-wk-old than 3-wk-old rats. In comparison, expression of $\mathrm{AT}_{2} \mathrm{R}$ mRNA was $~ 28$-fold less in in the kidneys of 6-wk-old
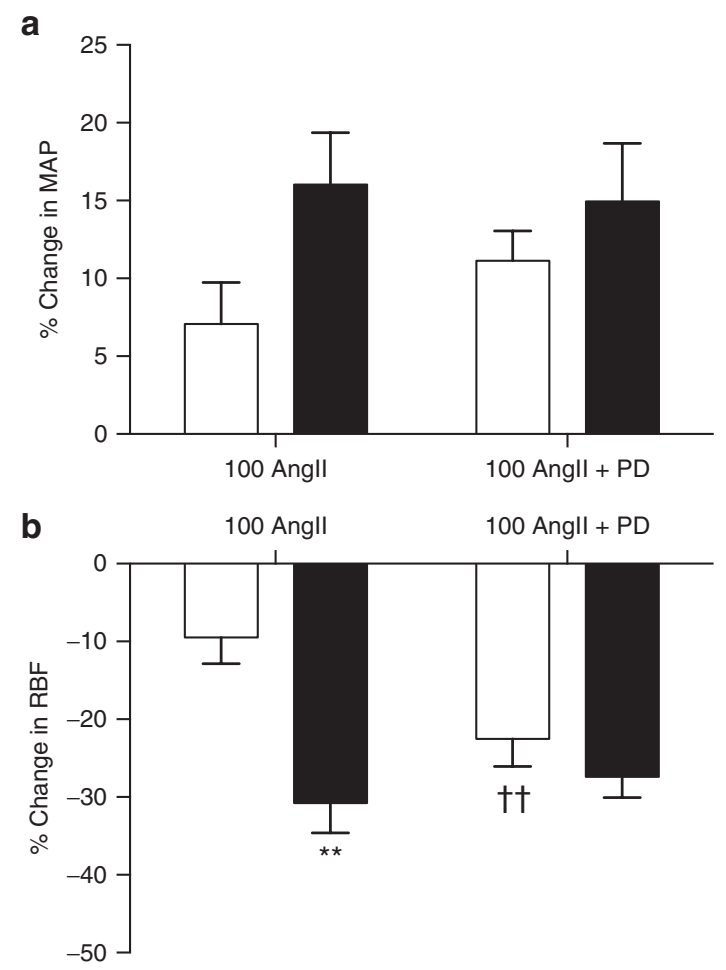

Figure 2. Pressor and renal vascular responses to angiotensin II in the presence and absence of $\mathrm{AT}_{2} \mathrm{R}$ blockade. Percent change in (a) mean arterial pressure (MAP) and (b) renal blood flow (RBF) from baseline in response to intravenous infusion of $100 \mathrm{ng} / \mathrm{kg} / \mathrm{min}$ angiotensin II in the presence and absence of PD123319 in 3-wk-old (white bars) and 6-wkold (black bars) male Sprague-Dawley rats. Data are presented as mean \pm SEM. $n=6$ per group. Data were analyzed using repeated-measures ANOVA using the factors age, treatment, and the interaction between age and treatment, followed by Bonferroni's post hoc tests. ${ }^{* *} P<0.001$ vs. the response of 3 -wk-old rats to $100 \mathrm{ng} / \mathrm{kg} / \mathrm{min}$ Angll. ${ }^{+t} P<0.01$ vs. the response of 3-wk-old rats to $100 \mathrm{ng} / \mathrm{kg} / \mathrm{min}$ Angll in the absence of PD123319. than 3-wk-old rats. Subsequently, the ratio of mRNA expression for $\mathrm{AT}_{2} \mathrm{R}_{\mathrm{AT}} \mathrm{R}$ was significantly lower in the kidneys of 6-wk-old rats $(0.24 \pm 0.07)$ compared with 3 -wk-old rats $(1.1 \pm 0.2)(P<0.01)$.

\section{DISCUSSION}

The major findings in this study were that during postnatal maturation of the kidney in rats, the $\mathrm{AT}_{2} \mathrm{R}$ modulates the response to AngII, blunting renal vasoconstriction. This effect is significantly attenuated with age in association with a developmental reduction in the ratio of $\mathrm{AT}_{2} \mathrm{R}$ to $\mathrm{AT}_{1} \mathrm{R}$ in the kidney. These data suggest that the $\mathrm{AT}_{2} \mathrm{R}$ plays an integral role in the regulation of $\mathrm{RBF}$ during the postnatal maturation of the kidney, providing protection against the vasoconstrictor effects of AngII. This knowledge may have important implications for the development of novel therapies that target the RAS for the treatment of hypotension and improvement of kidney perfusion in term and, in particular, preterm infants.

In humans, nephrogenesis begins in early gestation and is completed prior to birth. The kidney then continues to mature for approximately the first 6 mo of life, during which time significant changes in renal structure and function take place (6). In rats, however, nephron formation begins during the second half of gestation and continues for the first week following birth. The postnatal completion of nephrogenesis is then followed by a period of renal growth and maturation, which is completed in approximately the fourth week of postnatal life (16). In order to shed further light into the functional role of the $\mathrm{AT}_{2} \mathrm{R}$ during postnatal kidney development, we investigated the renal sensitivity of 3 -wk-old (immature) vs. 6-wk-old (young adult) rats to AngII, and the contribution of developmental changes in $\mathrm{AT}_{1} \mathrm{R}_{\text {and }} \mathrm{AT}_{2} \mathrm{R}$ expression to these responses.

In the current study, AngII induced significant pressor and renal vasoconstrictor effects in the 6-wk-old rats, similar to previous observations in adult male rats $(17,18)$. In contrast, the renal vasculature of the 3 -wk-old rats was significantly less sensitive to the vasoconstrictor actions of a high-dose infusion of AngII. Furthermore, we went on to demonstrate that pharmacological blockade of the $\mathrm{AT}_{2} \mathrm{R}$ potentiated the pressor and renal vascular responses to the highest dose of AngII administered in 3-wk-old rats. In contrast, $\mathrm{AT}_{2} \mathrm{R}$ blockade had
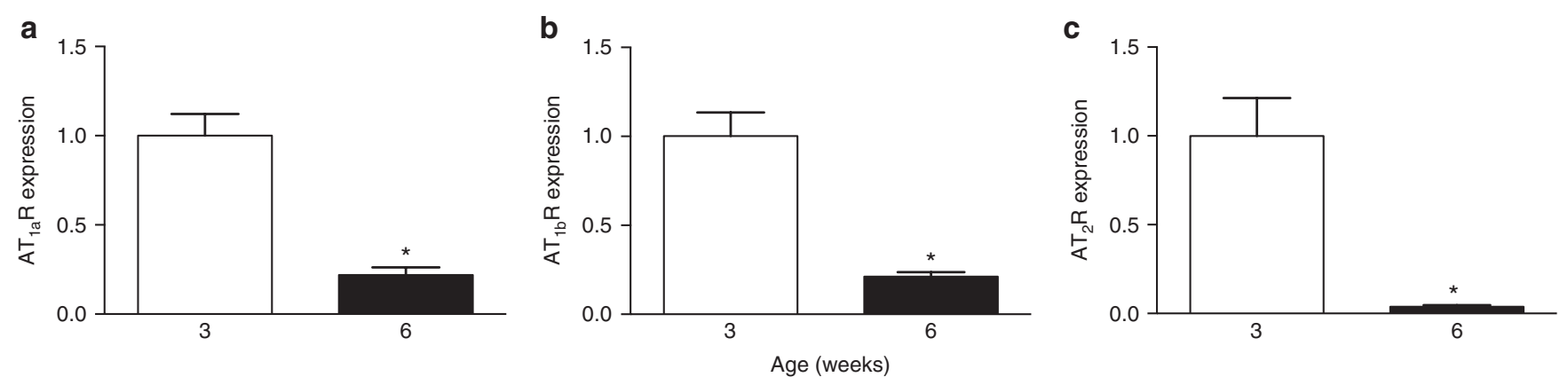

Figure 3. $A T_{1} R$ and $A T_{2} R$ mRNA expression. Relative renal mRNA expression of (a) $A T_{1} R,(\mathbf{b}) A T_{1 b} R$, and (c) $A T_{2} R$ in 3-wk old (white bars) and 6-wk-old (black bars) male Sprague-Dawley rats. Data are presented as mean \pm SEM. $n=8$ per group. Data were analyzed using an unpaired $t$-test. ${ }^{*} P<0.001$ vs. 3 -wk-old rats. 
little effect in 6-wk-old rats. Taken together, these results therefore indicate that the $\mathrm{AT}_{2} \mathrm{R}$ modulates the response to AngII to a much greater extent in the neonatal vs. adult kidney, contributing significantly to the attenuated renal vasoconstrictor response to AngII.

Our finding that the $\mathrm{AT}_{2} \mathrm{R}$ modulates the renal vasoconstrictor response to AngII in young rats contrasts with previous observations from two separate studies in lambs by Chappellaz and Smith $(10,19)$. They reported that the pressor and renal hemodynamic responses to intravenous infusion of AngII were age and dose-dependent such that they were significantly greater in 6-wk-old vs. 1-wk-old lambs (19). This is in keeping with our current observations in rats, supporting the notion that the neonatal vasculature is less sensitive to the vasoconstrictor effects of AngII. However, in contrast to the current study findings, they showed that the pressor and renal vasoconstrictor responses to AngII in lambs of both ages examined were sensitive to $\mathrm{AT}_{1} \mathrm{R}$ blockade but not affected by $\mathrm{AT}_{2} \mathrm{R}$ blockade $(10,19)$. This led to their conclusion that the $\mathrm{AT}_{2} \mathrm{R}$ does not significantly contribute to the decreased sensitivity of the renal vasculature of newborn sheep to AngII. Of course, this difference in study findings may be attributable to species differences and associated developmental differences in angiotensin receptor expression in the age of animals studied (sheep vs. rats). Further, we cannot rule out the possibility that differences in the dose of the $\mathrm{AT}_{2} \mathrm{R}$ antagonist (PD123319; 50-400 $\mu \mathrm{g} / \mathrm{kg}$ infusion over $2 \mathrm{~min}$ vs. $1 \mathrm{mg} / \mathrm{kg}$ constant infusion) and/ or the time-course of experiments may contribute. In particular, given the short plasma half-life of PD123319 (22 min), it is plausible that any influence of $\mathrm{AT}_{2} \mathrm{R}$ blockade on hemodynamic function in the lambs may not have been detectable by Chappellaz and Smith since MAP and RBF responses to AngII were only recorded $30 \mathrm{~min}$ (19) or at discrete time intervals $(5,30,60,90$, and $120 \mathrm{~min})(10)$ post-PD1233119 infusion. Finally, the confounding effects of anesthesia on basal RAS activation and hemodynamic function in the current study must also be taken into consideration. Studies examining the contribution of the $\mathrm{AT}_{2} \mathrm{R}$ to the modulation of renal function during postnatal maturation in conscious rats are required to confirm the findings of the current study.

The findings of the present study also support the notion that differences in vascular responsiveness to AngII between the young and adult rats is attributable to developmental differences in renal angiotensin receptor expression. In agreement with previous studies (11-14), assessment of renal $\mathrm{AT}_{1} \mathrm{R}$ and $\mathrm{AT}_{2} \mathrm{R}$ mRNA expression in the 3-wk-old- and 6-wk-old rat kidneys confirmed that $\mathrm{AT}_{1} \mathrm{R}$ and $\mathrm{AT}_{2} \mathrm{R}$ expression levels in the kidney decrease significantly with postnatal age. While $\mathrm{AT}_{1} \mathrm{R}$ and $\mathrm{AT}_{2} \mathrm{R}$ mRNA expression were similar in the 3-wk-old rat kidneys, $\mathrm{AT}_{2} \mathrm{R}$ mRNA expression decreased to a much greater extent than $\mathrm{AT}_{1} \mathrm{R}$ mRNA expression with postnatal age, such that the $\mathrm{AT}_{1} \mathrm{R}$ was the dominant angiotensin receptor subtype in the mature rat kidney. This was reflected by a significantly lower ratio of $\mathrm{AT}_{2} \mathrm{R}$ to $\mathrm{AT}_{1 \mathrm{a}} \mathrm{R}$ in the kidneys of 6-wk-old than 3 -wk-old rats. Furthermore, this is also consistent with what we have observed previously in other studies in male rats (11).
These data therefore indicate that the high renal $\mathrm{AT}_{2} \mathrm{R}$ expression during early postnatal life may contribute to the blunted renal vasoconstriction to AngII that is not seen in adult rats. In further support of this conjecture, it is well established that the $\mathrm{AT}_{2} \mathrm{R}$ functions via a nitric oxide (NO)-mediated pathway to produce cyclic GMP and increase vasodilatation (20). Certainly, there is abundant evidence in the literature that NO plays a significantly greater role in the maintenance of hemodynamic function in the neonatal vs. adult kidney, including providing protection against the vasoconstrictor effects of AngII in the newborn (21-24). Furthermore, there are reports that NO production in the renal vasculature is significantly greater in the newborn vs. adult renal vasculature under normal physiological conditions (4). It is therefore plausible that greater $\mathrm{AT}_{2} \mathrm{R}$ activation in the newborn vs. adult kidney may contribute to the enhanced functional role of NO in the newborn kidney as well as age-related differences in vascular responsiveness to AngII.

In future studies, it will also be important to examine the sex-specific contribution of the $\mathrm{AT}_{2} \mathrm{R}$ to the regulation of renal function in the immature kidney. A large body of evidence now exists that the RAS is differentially modulated between the sexes, and elicits sex-specific effects on renal function, including the $\mathrm{AT}_{2} \mathrm{R}(18,25-30)$. Moreover, we have previously identified significant sex differences in the postnatal ontogeny of many RAS components, at least in male and female rats (11).

In conclusion, our data indicate that the $\mathrm{AT}_{2} \mathrm{R}$ is an important regulator of RBF in the immature kidney, providing protection against the $\mathrm{AT}_{1} \mathrm{R}$-mediated vasoconstrictor effects of AngII. Although this finding is of primary physiological importance, it also bears potential clinical significance in the treatment of hypotension and renal hypoperfusion in term, and in particular, premature infants in whom postnatal kidney maturation is delayed. Future studies are now required to provide further insight into the potential of the $\mathrm{AT}_{2} \mathrm{R}$ as a therapeutic target in the immature kidney in pathophysiological states.

\section{METHODS}

\section{Animals}

All experiments were approved by the Monash University, School of Biomedical Sciences Animal Ethics Committee and were performed in accordance with the Australian Code of Practice for the Care and Use of Animals for Scientific Purposes. Ten-week-old male and female Sprague-Dawley rats were obtained from Monash Animal Services (Clayton, Victoria, Australia). Following a 1-2 wk acclimatization period, rats were mated. Pups were delivered at term and were weaned at postnatal day 21. Male pups were then randomly allocated to either the 3-wk or 6-wk-old experimental group ( $n=6-8$ in each group). All rats used in this study were housed under standard laboratory conditions and were fed a sodium-controlled diet ( $0.25 \%$ sodium chloride; Specialty Feeds, Glen Forrest, WA, Australia).

\section{Surgical Preparation}

The rats were anesthetized with an intraperitoneal injection of Inactin ( $150 \mathrm{mg} / \mathrm{kg}$; thiobutabarbital sodium, Sigma Aldrich, St Louis, MO) and placed on a servo-controlled heated table, maintaining rectal temperature at $37.5^{\circ} \mathrm{C}$. A tracheostomy was performed and the left carotid artery and jugular vein were cannulated for the measurement of MAP and infusion of maintenance fluids (isotonic saline with $2 \%$ w/v bovine serum albumin; Sigma-Aldrich, $5 \mathrm{ml} / \mathrm{kg} / \mathrm{h}$ ), respectively. Next, the left kidney was exposed through a subcostal flank incision. 
The left renal artery was carefully isolated and an ultrasonic flow probe $(0.5 \mathrm{~mm}$; Transonic Systems, Ithaca, NY) was placed around the artery for the continuous measurement of RBF $(18,26)$.

\section{Experimental Protocol}

Following surgery, the animals were allowed $1 \mathrm{~h}$ to stabilize. Basal MAP and RBF were then measured continuously for $30 \mathrm{~min}$. Following the basal period, intravenous infusion of graded doses of AngII (10 and $100 \mathrm{ng} / \mathrm{kg} / \mathrm{min}$ ) commenced. Each dose of AngII was administered for $10 \mathrm{~min}$, with at least $10 \mathrm{~min}$ allowed for return of MAP and RBF to baseline between each dose. At each dose of AngII, the peak response in MAP and RBF was recorded. Finally, the peak measurements in response to $100 \mathrm{ng} / \mathrm{kg} / \mathrm{min}$ AngII were repeated in the presence of $\mathrm{AT}_{2} \mathrm{R}$ blockade using PD123319 (1 mg/kg intravenous bolus $+1 \mathrm{mg} / \mathrm{kg} / \mathrm{h}$ continuous infusion).

\section{Real-Time RT-PCR}

In a separate cohort of 3 - and 6-wk-old male rats, kidneys were removed and weighed. Total RNA was extracted from kidney tissue using the RNeasy mini extraction kit, as per the manufacturer's instructions (Qiagen, Chadstone, VIC, Australia). Total RNA was reversed transcribed into cDNA using the $5 \times$ iScript reverse transcription supermix for RT-qPCR (Bio-Rad Laboratories, Gladesville, NSW, Australia). $\mathrm{AT}_{1 \mathrm{a}} \mathrm{R}, \mathrm{AT}_{1 \mathrm{~b}} \mathrm{R}$ and $\mathrm{AT}_{2} \mathrm{R}$ mRNA gene expression were then measured using Taqman gene expression assays (Life Technologies, Mulgrave, VIC, Australia) and the Applied Biosystems 7900HT Fast RT-PCR system (Life Technologies). Samples were run in triplicate with $18 \mathrm{~S}$ rRNA as the internal housekeeping gene. Calculations of relative gene expression were carried out with Realplex software (Life Techologies) using the comparative $\mathrm{C}_{\mathrm{T}}$ method $(11,17)$.

\section{Statistical Analyses}

All data are presented as mean \pm SEM. To compare differences in baseline variables between treatment groups and angiotensin receptor mRNA gene expression, data were analyzed using Student's unpaired $t$-tests. MAP and RBF data were analyzed using repeated-measures ANOVA with the factors comprising of either age (3 or $6 \mathrm{wk}$ ) and dose $(10$ or $100 \mathrm{ng} / \mathrm{kg} / \mathrm{min}$ ), or age ( 3 or $6 \mathrm{wk}$ ) and treatment (AngII or AngII + PD123319), and their interaction, followed by Bonferroni's post hoc analysis. Two-tailed $P$ values $\leq 0.05$ were considered statistically significant.

\section{ACKNOWLEDGMENTS}

We acknowledge the technical assistance of Rebecca Flower.

\section{STATEMENT OF FINANCIAL SUPPORT}

This work was supported by the National Health and Medical Research Council of Australia Project Grant \#490919, and K.M.D. was supported by Research Fellowship \#1041844.

\section{REFERENCES}

1. Toth-Heyn P, Cataldi L. Vasoactive compounds in the neonatal period. Curr Med Chem 2012;19:4633-9.

2. Kluckow M. Low systemic blood flow and pathophysiology of the preterm transitional circulation. Early Hum Dev 2005;81:429-37.

3. Noori S, Seri I. Pathophysiology of newborn hypotension outside the transitional period. Early Hum Dev 2005;81:399-404.

4. Ratliff B, Rodebaugh J, Sekulic M, Dong KW, Solhaug M. Nitric oxide synthase and renin-angiotensin gene expression and NOS function in the postnatal renal resistance vasculature. Pediatr Nephrol 2009;24:355-65.

5. Fong D, Denton KM, Moritz KM, Evans R, Singh RR. Compensatory responses to nephron deficiency: adaptive or maladaptive? Nephrology (Carlton) 2014;19:119-28.

6. Chevalier RL. Mechanisms of fetal and neonatal renal impairment by pharmacologic inhibition of angiotensin. Curr Med Chem 2012;19:4572-80.

7. Jones ES, Vinh A, McCarthy CA, Gaspari TA, Widdop RE. AT2 receptors: functional relevance in cardiovascular disease. Pharmacol Ther 2008; 120:292-316.

8. Gomez RA, Tufro-McReddie A, Everett AD, Pentz ES. Ontogeny of renin and AT1 receptor in the rat. Pediatr Nephrol 1993;7:635-8.
9. Monument MJ, Smith FG. Age-dependent effects of captopril on the arterial baroreflex control of heart rate in conscious lambs. Exp Physiol 2003;88:761-8.

10. Chappellaz ML, Smith FG. Systemic and renal hemodynamic effects of the AT1 receptor antagonist, ZD 7155, and the AT2 receptor antagonist, PD 123319, in conscious lambs. Pflugers Arch 2007;453:477-86.

11. Sampson AK, Moritz KM, Denton KM. Postnatal ontogeny of angiotensin receptors and ACE2 in male and female rats. Gend Med 2012;9:21-32.

12. Tufro-McReddie A, Harrison JK, Everett AD, Gomez RA. Ontogeny of type 1 angiotensin II receptor gene expression in the rat. J Clin Invest 1993;91:530-7.

13. Shanmugam S, Lenkei ZG, Gasc JM, Corvol PL, Llorens-Cortes CM. Ontogeny of angiotensin II type 2 (AT2) receptor mRNA in the rat. Kidney Int 1995;47:1095-100.

14. Robillard JE, Schutte BC, Page WV, Fedderson JA, Porter CC, Segar JL. Ontogenic changes and regulation of renal angiotensin II type 1 receptor gene expression during fetal and newborn life. Pediatr Res 1994;36: 755-62.

15. Butkus A, Albiston A, Alcorn D, et al. Ontogeny of angiotensin II receptors, types 1 and 2, in ovine mesonephros and metanephros. Kidney Int 1997;52:628-36.

16. Cha JH, Kim YH, Jung JY, Han KH, Madsen KM, Kim J. Cell proliferation in the loop of henle in the developing rat kidney. J Am Soc Nephrol 2001;12:1410-21.

17. Sampson AK, Moritz KM, Jones ES, Flower RL, Widdop RE, Denton KM. Enhanced angiotensin II type 2 receptor mechanisms mediate decreases in arterial pressure attributable to chronic low-dose angiotensin II in female rats. Hypertension 2008;52:666-71.

18. Hilliard LM, Nematbakhsh M, Kett MM, et al. Gender differences in pressure-natriuresis and renal autoregulation: role of the Angiotensin type 2 receptor. Hypertension 2011;57:275-82.

19. Chappellaz ML, Smith FG. Dose-dependent systemic and renal haemodynamic effects of angiotensin II in conscious lambs: role of angiotensin AT1 and AT2 receptors. Exp Physiol 2005;90:837-45.

20. Carey RM, Jin X, Wang Z, Siragy HM. Nitric oxide: a physiological mediator of the type 2 (AT2) angiotensin receptor. Acta Physiol Scand 2000;168:65-71.

21. Rodebaugh J, Sekulic M, Davies W, et al. Neuronal nitric oxide synthase, nNOS, regulates renal hemodynamics in the postnatal developing piglet. Pediatr Res 2012;71:144-9.

22. Ballèvre L, Thonney M, Guignard JP. Nitric oxide modulates glomerular filtration and renal blood flow of the newborn rabbit. Biol Neonate 1996;69:389-98.

23. Sener A, Smith FG. Glomerular and tubular responses to N(G)-nitro-Larginine methyl ester are age dependent in conscious lambs. Am J Physiol Regul Integr Comp Physiol 2002;282:R1512-20.

24. Solhaug MJ, Ballèvre LD, Guignard JP, Granger JP, Adelman RD. Nitric oxide in the developing kidney. Pediatr Nephrol 1996;10:529-39.

25. Brown RD, Hilliard LM, Head GA, Jones ES, Widdop RE, Denton KM. Sex differences in the pressor and tubuloglomerular feedback response to angiotensin II. Hypertension 2012;59:129-35.

26. Hilliard LM, Jones ES, Steckelings UM, Unger T, Widdop RE, Denton KM. Sex-specific influence of angiotensin type 2 receptor stimulation on renal function: a novel therapeutic target for hypertension. Hypertension 2012;59:409-14.

27. Sampson AK, Hilliard LM, Moritz KM, et al. The arterial depressor response to chronic low-dose angiotensin II infusion in female rats is estrogen dependent. Am J Physiol Regul Integr Comp Physiol 2012;302:R15965.

28. Denton KM, Hilliard LM, Tare M. Sex-related differences in hypertension: seek and ye shall find. Hypertension 2013;62:674-7.

29. Hilliard LM, Mirabito KM, Denton KM. Unmasking the potential of the angiotensin AT2 receptor as a therapeutic target in hypertension in men and women: what we know and what we still need to find out. Clin Exp Pharmacol Physiol 2013;40:542-50.

30. Hilliard LM, Sampson AK, Brown RD, Denton KM. The "his and hers" of the renin-angiotensin system. Curr Hypertens Rep 2013;15:71-9. 